\title{
Management and Harmonization of the Emotional States of Parents of Children with the Special Needs
}

\author{
Alla Dushka,Tetiana Skrypnyk, Vitalii Lunov, Yaroslav Tsekhmister, Liana Onufriieva, \\ Kocharian Aleksander, Barinova Natalia
}

\begin{abstract}
The article is sanctified to the question of study of the psycho-emotional states parents as a ponderable lever of forming of paternal position and motivation. It assists becoming and their active voice in the processes of vital functions of own child and also acquisition of possibility self-realization. Our research is based on the theory of self-organizing systems, the concept of synergetic as a paradigm of post-non-classical science, socio-humanitarian and social synergetic. Expediency of application synergetic approach for the study of the psycho-emotional states of parents consists in that situation in that there are families of children with the special necessities characterized by instability and unforeseeableness, it is here known that exactly a synergetic engages in the study of the unstable systems and opens possibilities for their self-organization. Application of psycho-diagnostic testing allowed to reduce the features of the emotional states us in 447 families, where children with the special necessities. We have developed a psycho-synergetic intervention technology, which consists of 5 stages.

Application of this technology educed considerable improvements and harmonization of the emotional states parents of children with the special needs, that on the whole positively affected internal domestic situation on the whole.
\end{abstract}

Keywords : paternity, special educational needs, emotional state, synergetic, self-organization.

Revised Manuscript Received on November 15, 2019

* Correspondence Author

Alla Dushka, Doctor of psychological sciences, Associate professor,

Chief Scientist of the Department of Psychological and Pedagogical Support of Children with Special Needs Nichola Yarmachenko Institute of Special Pedagogics and Psychology of National Academy of Educational Sciences of Ukraine

Tetiana Skrypnyk ,Doctor of psychological sciences, professor of the Department of Special Psychology, Special and Inclusive Education, Institute of Human Sciences of Borys Grinchenko Kyiv University Vitalii Lunov* ,PhD in Psychology, Associate Professor, Associate Professor of the Department of General and Medical Psychology of the Bogomolets National Medical University Email: lunyov_vitaliy@ukr.net, Tel: +38-0502536604; Fax: +380 (44) 2883320

Yaroslav Tsekhmister , Corresponding Member of the National Academy of Pedagogical Sciences of Ukraine, Doctor of Pedagogical Sciences, Professor,

Liana Onufriieva , Ph. D. in Psychology, Assistant Professor, Professor of the Department of General and Applied Psychology, Head of the Department of General and Applied Psychology, Kamianets-Podilskyi National Ivan Ohiienko University, Kamianets-Podilskyi, Ukraine.

Kocharian A., Barinova N., Department of Psychological Counseling and Psychotherapy, V.N. Karazin Kharkiv National University, Kharkiv, Ukraine

\section{INTRODUCTION}

A problem of creation and organization of the system of effective psychological help to the parents of children with the special needs presently is extraordinarily actual. From one side, the quantity of such children grows from year to year, and on the other hand, in Ukraine the system of psychological support of these children and their families is absent until now. Based on the analysis of the work of domestic and foreign researchers (N. Bastun, M. Betshaw, T. Kravchenko, G. Kukuruza, D. Lobato, I. Lungul, Helen L. McElreath, K. Ostrovskaya, M. Radchenko, K. Flake-Hobson et al.) found that the birth of a child with special needs belongs to significant psychotraumatic, crisis factors for the whole family and are experienced as: experiencing "doom after a catastrophic event" (D. Bowlby), "chronic stress situation" (G. Kukuruza)," Chronic extremism "(M. Radchenko), a feeling of discomfort and alienation; experiences of existential crisis; loss of meaning in life; emotional reactivity; high level of anxiety, vulnerability, emotional lability, increased irritability interpretative stress: anxiety, affective tension, panic, state of confusion, feelings of helplessness (L. Borshchevskaya, L. Zibrova, I. Ivanova).

After traumatic experiences related to the birth and upbringing of a child with psychophysical deviations, for many parents the period of depression begins. This can be the result of prolonged emotional stress, coupled with excessive physical overload, family conflicts associated with rejection of the diagnosis, mutual accusations, excellent views on treatment, development and education like that. The consequences of action of these factors can show up in: violations of family interactions( "escape" of parents in work, renunciation, or, vice versa, is excessive dedication itself to the child; domestic conflicts - up to a divorce etc.), negative ideas and experiencing of parents(crash of all hopes and plans on the future, tragic perception of life etc.), forming of pathological educator strategies(underestimation of possibilities of child or excessive requirements to her, over guardianship, permissiveness etc.), violation of the social functioning of family (loss of social connections, aggressive behavior to the outside world) $[25,27,30]$. In the conditions of unprotected ness and vagueness, a vital route such families become one of the most not protected task forces [12]. At parents of a birth of the child with development disturbances often causes experiences of own inconsistency, feeling of fault and the latent auto destruction, crisis of self-identification and valuable orientations. 
Non-acceptance child with violations of the psychophysical development by society, social stigmatization on reasons (prosecutions of parents) often cause social reserve and social isolation of the family. Permanent life in such conditions leads to the predominance of negative and non-productive psycho-emotional states in parents, which adversely affects the adequacy of their assessment of the child's capabilities, and then the prospects for its development. Only an active parental position, faith and knowledge are the key to the successful and all-round development of their child [6;7].

At present, scientists (E. Eidemiller, R. Mukhamedrakhimov, V. Kobilchenko, T. Skrypnyk, V. Yustitskis et.all) have developed a significant range of methods of psychological care for children with psychophysical deviations, new ones are being actively developed and improved: traditional directions of research in the personal sphere of parents such children; adaptation mechanisms that prevent the psychological destruction of their mental organization; approaches to the introduction of psychological and pedagogical support for such families. So, it is proved that the application of the practice of awareness [4] increases the self-esteem of parents and contributes to the emergence of their ability to actively overcome and reduce stress. According to the family stress theory, resources play an integral role in adapting families to stressful circumstances (Mc. Cubbin, 1979). Perry's model (2004) includes personal and family system resources as important elements that can affect the relationship between the presence of a child with SNs: positive and negative parental involvement outcomes).

It is also determined that the development of parents' focused attention to all issues related to children with special needs will reduce the state of their stress and suffering and will also enable them to acquire the ability to respond correctly to current events and make effective decisions that will improve the current situation $[1,2]$.

Available biographical or methodological sources that open new perspectives of the vision of the topic of paternity for children with special needs and provide a positive voice of this problem [5; 8 - 11, 24-32].

Despite numerous developments concerning the situation of children with psychophysical deviations and their parents, we believe that the issue of the psycho-emotional states of parents as a weighty leverage for forming a parent position and motivation and an active component for participation in the processes of the life of a child with special needs remains insufficiently studied. At the same time, the need for a scientific justification of modern theoretical and methodological foundations for the development of a psychological support system for families of such children, which would ensure the establishment of productive partnerships with parents. This will allow them to obtain the status of real participants in the interdisciplinary team support of the child, to actively influence the process of learning and development of the child, as well as their own vital activity.

\section{MATERIALS AND METHODS}

Our research is based on a synergetic approach, namely: the theory of self-organizing systems (G. Haken, I. Prigogine and others), the concepts of synergetic as a paradigm of post-non-classical science (T. Kun), social and humanitarian
(V. Aseev, V. Vaidlikh, V. Ebeling K) and social synergetic (D. Vico, A. J. Toynbee, O. Spengler). We believe that the synergetic approach is advisable to apply for studying the psycho-emotional states of parents because the situation in which families of children with special needs are located is characterized by an unstable and unpredictable one. As is known, it is synergetic that is engaged in the study of unstable systems and opens up opportunities for their self-organization [14]. According to the theory of sociodynamics, from the change and development of society, social structures, processes and phenomena are subject to similar tendencies of transformation. Now, all of the crisis's contradictory and controversial processes taking place in our country affect all social institutions, among the most vulnerable are families that educate children with disorders of psychophysical development. Given the lack of social guarantees, consistent medical care and the unhindered implementation of the right to education, these families are in an unstable, and sometimes extreme, crisis. Excessive and prolonged psychological pressure felt by the parents of such children, as well as the situation of uncertainty, cause psycho-traumatic consequences - individual psychosocial and social maladaptation.

According to the synergetic approach, the family is a complex, contradictory, dynamic system that is in a state of non-equilibrium and is subject to laws of a nonlinear nature [17 - 19]. It is this instability that determines the possibility of transition to a qualitatively new state with a higher level of organization and productivity, and the loss of functional non-productive sustainability triggers a mechanism of self-organization and the formation of new effective structures based on the acquired innovative potential $[13,15]$. Any open system has the following qualitative characteristics such as: openness, nonlinearity, instability, ability to self-organization [16]. In our opinion, these parameters are coveted in families of children with special needs, because they will testify to the high level of adaptation and self-realization of the family as a system and each of its members [6; 7]. Open self-organization systems are called "living systems", and their important feature is that they develop in the direction of achieving the state of "mobile equilibrium" (non-stability). Traditionally, "non-stability" is perceived as a negative characteristic, and in contrast to it, stability is like a desired state, which should be sought. But synergetic reveals other aspects of this notion: instability, instability and imbalance is a necessary condition for the emergence of a new organization, a new order, new systems, that is, development (Ilya Prigogine); due to this, there is a search for own boundaries and opportunities for direct interaction with others. So, the synergetic approach focuses on a holistic perception of the world of man and society, in the view of mutual influence, coordinated joint life activity [21-23]. Despite the important guidelines developed in the framework of synergetic, and the main goal of our intervention, we defined the developed technology of psychological and synergetic, which has the following stages of implementation: motivational, conceptual, adaptive, creative, monitoring-perspective. We have established the relationship between the methods of psychological intervention and psychological mechanisms, on the one hand, and synergistic ideas and 
technologies, on the other (Table 1).

\begin{tabular}{|c|c|c|c|}
\hline Stage & $\begin{array}{l}\text { Psychological methods } \\
\text { affecting the state of parents }\end{array}$ & $\begin{array}{l}\text { Mechanisms realization } \\
\text { of corresponding method }\end{array}$ & Positions of synergetic \\
\hline 1th, motivational & $\begin{array}{l}\text { Establishment of contact, } \\
\text { absolute acceptance; } \\
\text { adjusting initial } \\
\text { stages of therapeutic alliance. } \\
\text { Communication as outside } \\
\text { subject dialogue process. }\end{array}$ & $\begin{array}{l}\text { empathy; motivation and } \\
\text { installation; parents' } \\
\text { awareness of their personal } \\
\text { characteristics, beliefs. }\end{array}$ & $\begin{array}{l}\text { Instability as a state of } \\
\text { readiness } \\
\text { transformations, } \\
\text { formation of a new order } \\
\text { and dynamic states; no } \\
\text { equilibrium dynamics; } \\
\text { bifurcation mechanisms. }\end{array}$ \\
\hline 2th, conceptual & $\begin{array}{l}\text { Interaction within the } \\
\text { therapeutic } \\
\text { Modeling. The method of } \\
\text { "verbal generalization." } \\
\text { Formation of a research } \\
\text { position among parents. }\end{array}$ & $\begin{array}{l}\text { mechanisms: } \\
\text { - to emotional } \\
\text { self-regulation; } \\
\text { - personality teleology's; } \\
\text { - general (collective) } \\
\text { to activity. }\end{array}$ & $\begin{array}{l}\text { The theory of attractors. } \\
\text { Nonlinearity as a } \\
\text { multivariate path of } \\
\text { development. } \\
\text { mechanism of resonant } \\
\text { excitation: a no equilibrium } \\
\text { system is sensitive only to } \\
\text { impacts coordinated with its } \\
\text { own nature. }\end{array}$ \\
\hline 3th, adaptive & $\begin{array}{l}\text { Stage-by-stage introduction of } \\
\text { strategy of development of } \\
\text { child and transformation of } \\
\text { situation is in family; fixing of } \\
\text { positive dynamics and } \\
\text { hindrances; search of } \\
\text { additional internal and } \\
\text { external resources. }\end{array}$ & $\begin{array}{l}\text { Mechanisms: } \\
\text { sensorimotor integration; - } \\
\text { psychic and psychosocial } \\
\text { adaptation; -emotional } \\
\text { intelligence. }\end{array}$ & $\begin{array}{l}\text { Integration of instabilities } \\
\text { in the system (processes of } \\
\text { local ordering). } \\
\text { Synchronization as a } \\
\text { property to harmonize the } \\
\text { rhythm of joint life; } \\
\text { co-evolutionary principle }\end{array}$ \\
\hline 4th, creative & $\begin{array}{l}\text { Methods of estimation of } \\
\text { professionalism of specialists } \\
\text { that read with a child and their } \\
\text { command work. } \\
\text { Methods regulators on } \\
\text { productive influence on } \\
\text { unimpeded introduction of } \\
\text { processes of educating and } \\
\text { development child. }\end{array}$ & $\begin{array}{l}\text { Motivational } \\
\text { self-regulation, } \\
\text { mechanisms of group } \\
\text { dynamics. External } \\
\text { reflection as an evaluation } \\
\text { of the activities of others } \\
\text { according to certain } \\
\text { criteria. }\end{array}$ & $\begin{array}{l}\text { The principle of "sprawl of } \\
\text { small" (amplification of the } \\
\text { impact) as a property of } \\
\text { nonlinearity. } \\
\text { emergence of the ability to } \\
\text { self-organization and the } \\
\text { properties of the "open } \\
\text { system". High adaptability, } \\
\text { as the ability to integrate } \\
\text { into the environment. }\end{array}$ \\
\hline $\begin{array}{l}\text { 5th, } \\
\text { monitoring-perspective }\end{array}$ & $\begin{array}{l}\text { Attachment to parent } \\
\text { communities; Establishment } \\
\text { of productive cooperation } \\
\text { with specialists in medical and } \\
\text { social spheres; The } \\
\text { development of a further } \\
\text { development plan based on } \\
\text { the experience gained, as well } \\
\text { as the emergence of new needs } \\
\text { and expectations. }\end{array}$ & $\begin{array}{l}\text { Internal reflection as } \\
\text { ability of parents to carry } \\
\text { out the estimation of own } \\
\text { achievements, analysis } \\
\text { internal domestic situation } \\
\text { and self-realization of each } \\
\text { of family members in } \\
\text { society. }\end{array}$ & $\begin{array}{l}\text { Completion of the internal } \\
\text { sample; The transition } \\
\text { system is a process that lies } \\
\text { between the possible and } \\
\text { the real. Completion of the } \\
\text { face itself; The formation of } \\
\text { their own capabilities, } \\
\text { which are formed as a result } \\
\text { of the correlation and } \\
\text { interaction (synergy) of the } \\
\text { person and society. }\end{array}$ \\
\hline
\end{tabular}

Table: 1. The relationship between psychological and pedagogical methods of impact, the mechanisms of their implementation and the provisions synergetic at each stage of psychological (intervention)

\section{Research Methods}

447 parents of children with special needs took part in the study, who received assistance in such centers and organizations of Ukraine as: Odessa Center for Vocational Rehabilitation of the Disabled (Odesa Oblast, Kholodnaya Balka Village), State Specialized Children's Clinical Sanatorium "Hadzhibey" (Odessa, Usatovo village), Psychological Assistance Center "Psyche" in Odessa. For comparison were inspected also 408 parents of children with
[Table-1]

- general (collective)

excitation: a no equilibrium system is sensitive only to impacts coordinated with its own nature. local ordering). rhythm of joint life; principle

The principle of "sprawl of small" (amplification of the emergence of the ability to self-organization and the properties of the "open system". High adaptability, as the ability to integrate

normal development. To assess the emotional states, we have used the following methods: the study of the parent attitude to the child (A. Varga, V. Stolin) the modified method "The State-Trait Anxiety Inventory" (Spielberger C. D.), The Positive and Negative Affect Schedule (Watson D., Clark L A, Telegen A), "Diagnostics of depressive states" (V. Zhmurov), projective technique (Picture test) "Tree-Self-Portrait-Terrain" (T. Viskovatova).

The got results on these methodologies, on the whole, researches confirmed [3], that the features of development of children, their stability, duration and irreversibility, influence on the depth of experiencing of parents. So, $34 \%$ of parents have determined that the

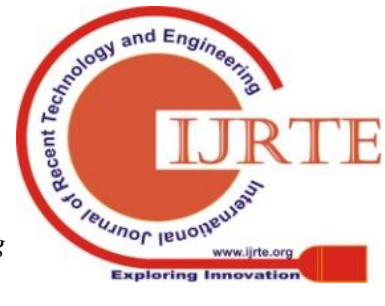


traumatic factor of their emotional state is the violation in children of the ability to establish adequate contact with the surrounding society and with them personally. It is difficult for parents to explain the features of their child's psycho-emotional manifestations, which causes the desire to limit or minimize social contacts, to close with oneself with their problems (38\%).

We have outlined a special social and psychological portrait of parents of children with special needs: a decrease in the mental tone, loss of the "taste" of life, career prospects, lack of confidence in the implementation of professional plans, high rates of depressiveness and anxiety, excitability combined with rapid exhaustion (in comparison with parents who raise children with normative development). Parents of children with special needs also showed a strong sense of guilt over past events and a sense of helplessness in the face of life's difficulties, which is combined with a sense of hopelessness. Based on the provisions of synergetic, we implemented a psychological and synergistic technology for helping parents of children with special needs, which was carried out in the format of individual and group sessions and had the following stages:

1) The motivational: activating the desire of parents to actively participate in the development of self-help strategy and technology, implemented through communication as an equal dialogue process, in which a common semantic field is formed and trusting open relationships are established (at this stage we reckoned the crisis state of parents (bifurcation point) as a condition disclosure of the motivational and personal resource);

2) conceptual, where, as a result of the established psychotherapeutic alliance, the goals and assumptions of the parents' own responsibility for the process of change and positive changes are laid (here the direction of development took place, taking into account the multivariance (nonlinearity) and alternative ways and rates of development); 3) The adaptive: the emergence of socio-psychological adaptation through the establishment of constant feedback and the convergence of goals between all members of the family, between them and the specialist (specialists), and between them and the social structures with which they interact. A weighty factor of changes at this stage is the introduction of consistent thoughtful and targeted assistance to both children and parents themselves in the psycho-corrective and psychotherapeutic classes. Here, the development of assistance methods was based on the unique characteristics of each family as a microsocial system and also the format of dialogue with parents was applied and their involvement in immediate active participation (the law of resonant excitation, the phenomenon of synchronization and co-evolution); on group employments(sessions) took place treatments of adequate forms of behavior and reacting on the problems of child, on the basis of achievements in cognitive and emotional spheres; formation of conflict resolution skills in interpersonal communication; techniques of self-regulation of emotional states: anxiety (personal and situational), affective, depressive, autistic, internal discomfort.

4) The creative, where applied methods and methods were used to constructively influence the existing undesirable situation and transform it into the desired one; the emergence of the ability to adapt to changes in circumstances and creatively use the context of the situation to implement a specific development strategy for the child; distribution (generalization) of the formed skills and acquired neoplasms in vital activity. Important in this case is the continuous use of feedback (the mechanism of ordering) the accumulation of innovative properties as the basis for constant changes and the ability to self-organize (cumulative effect). Due to this, parents acquire the ability to adapt to changing circumstances and creatively use the context of the situation to implement a specific development strategy for the child;

5) monitoring-perspective: assessment of the success of the development and future planning with a reference to the desired results, taking into account the potential risks, as well as the new internal and external resources. Due to this, the parents realize the acquired opportunities at a broader level, in the society, the self-realization of each member of the family.

The purpose of providing psychological assistance to parents of children with psychophysical deviations is the formation of the parents' ability to self-organize, provides the opportunity to plan the life activity of the child and the family, to achieve success in the situation with the child, to acquire optimal self-realization in the micro-society (family) and in the macrocosm (society). Positive psycho-emotional states of parents in this process, as well as factors, are a consequence of a successful course.

Expected results of the introduction of technology:

1) conditions are created for parents to manage their own psycho-emotional states: activation of their motivation, based on the child's situation; the disclosure of expectations and aspirations, the formulation of goal-setting; active involvement in the processes of learning and development of the child, as well as the acquisition by the family of the ability to function fully in the society; parents' ability to exercise self-regulatory functions and realize their potential;

2) internal communication within the family (between all members) and external communication (family - other social structures);

3) develop the ability of parents to mobilize their own resources, the ability to make choices in accordance with a certain strategy of positive transformations, which promotes the development of flexibility, plasticity and constructiveness of psycho-emotional and behavioral manifestations in social situations both within the family (micro-society) and outside (macrocosm), as well as the ability to achieve psycho-emotional stability (resistance to destructive influences and risks) both in relation to their own manifestations, and relates flax functioning of the entire family.

After our psychological interference we carried out the repeated inspection of parents on the diagnostic tool chosen by us.

\section{RESULTS}

Despite a large array of diagnostic data in our study, we will comment only on certain positions, some of them. An important indicator of the inner well-being of a person is a state of self-confidence, as well as a moderate dependence on the opinions of the surrounding people. And as a consequence, the parents of children with special needs demonstrate a high level of personal anxiety, which negatively affects both their self-realization and the situation of their own child. The table

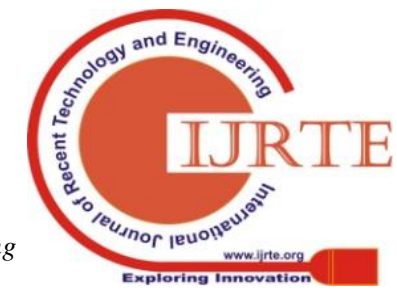


shows the indicators of personal anxiety before and after [Table-2] psychological intervention.

\begin{tabular}{|c|c|c|c|c|c|c|c|}
\hline $\begin{array}{l}\text { Group of } \\
\text { examinee }\end{array}$ & $\begin{array}{l}\text { The mean } \\
M \pm m\end{array}$ & $\begin{array}{l}\text { Dispersio } \\
\text { n D }\end{array}$ & $\begin{array}{l}\text { Median } \\
\text { M }\end{array}$ & $\begin{array}{c}\text { Asymmetr } \\
\mathbf{y} \gamma_{1}\end{array}$ & $\begin{array}{c}\text { Excess } \\
\gamma_{2}\end{array}$ & $\begin{array}{c}\mathbf{U} \\
\text {-statistics }\end{array}$ & p- value \\
\hline $\begin{array}{r}\text { Before an } \\
\text { experiment }\end{array}$ & $\begin{array}{l}42.908 \pm \\
0.405\end{array}$ & 8.564 & 39 & 0.046 & -1.829 & \multirow[t]{2}{*}{86648.5} & \multirow[t]{2}{*}{$0.001 * * *$} \\
\hline $\begin{array}{r}\text { After an } \\
\text { experiment }\end{array}$ & $\begin{array}{l}44.204 \pm \\
0.401\end{array}$ & 8.473 & 42 & 1.325 & 1.252 & & \\
\hline
\end{tabular}

Table: 2. Indicators of personal anxiety in parents of children with special needs $(n=447$; before and after the experiment)

As can be seen from the data presented in the table, the indicator of moderately high personal anxiety, which was before the parents' intervention, changed at a significant level

\begin{tabular}{|c|c|c|c|}
\hline The mean: $\mathbf{M} \pm \mathbf{m}$ & The mean: $\mathbf{M} \pm \mathbf{m}$ & U- statistics & p- value \\
\hline Before an experiment & After an experiment & 44944 & $0.001 * * *$ \\
\hline $0.676 \pm 0.013$ & $0.449 \pm 0.007$ & & \\
\hline
\end{tabular}

Table: 3. Mean values of scale "Attitude toward failures» methodologies are "Questionnaire of paternal relation" (before and after an experiment)

After application of technology of interference, the level of negative perception of errors and failures of child went down

\begin{tabular}{|c|c|c|c|}
\hline The mean: $\mathbf{M} \pm \mathbf{m}$ & The mean: $\mathbf{M} \pm \mathbf{m}$ & U- statistics & p- value \\
\hline Before an experiment & After an experiment & 39020 & $0.001 * * *$ \\
\hline $0.617 \pm 0.006$ & $0.556 \pm 0.004$ & & \\
\hline
\end{tabular}

Table : 4. Mean values of scale are "Symbiosis" methodologies are "Questionnaire of paternal relation" (before and after an experiment)

\begin{tabular}{|c|c|}
\hline The mean: $\mathbf{M} \pm \mathbf{m}$ & The mean: $\mathbf{M} \pm \mathbf{m}$ \\
\hline Before an experiment & After an experiment \\
\hline
\end{tabular}

Level of cooperation for the parents of children with the special needs since we applied psychological technology grew considerably, and statistical calculations convince of efficiency of measures that took place: a capacity for co-operation with a child grew for parents from a very moderate value $(0.457 \pm 0.007)$ to very expressed $(0.640 \pm$ $0.005)$ at a high level for certain $(\mathrm{p}<0.001)$.

It is set by us also, that meaningful changes happened on the row of indicators. In particular, on a scale "Acceptance - child with deviation" parents have positive changes at meaningful level, taking into account that it is possible to assert about ability to accept a child such, what he is. Meaningful changes happened and in regard to parents to the failures of child. So, the level of negative perception of errors and failures went down from comparatively high (on the average $0.676 \pm 0.013$ ) and middle $(0.449 \pm 0.007)$. The level of neuroticism of parents of children with special needs has decreased from high to medium, and the level of depression has reached an average level. The level of anxiety, mood swings (from excitation to depression) approached the norm, which positively affected the performance of their professional towards harmonization, which is associated with increased self-confidence and acceptance of events as they are.

Expressive changes were attained on such descriptions of emotional intellect of parents, as attitude toward failures, symbiosis and capacity for co-operation (tables 3-5).

for parents from comparatively high (on the average $0.676 \pm$ $0.013)$ to moderate $(0.449 \pm 0.007)$; the looked after dynamics is real and statistically meaningful.

[Table-4]

The presented results testify that for parents the degree of expressed of symbiosis went down to the moderate level $(0.556 \pm 0.004)$.

[Table-5]

\begin{tabular}{|c|c|}
\hline U- statistics & p- value \\
\hline 5528 & $0.001^{* * *}$ \\
\hline
\end{tabular}

duties by parents, which was confirmed by the method of conversation.

At the same time, on results a questionnaire parents it is found out that for them:

- attention increased to the own necessities, experiencing and ideas;

- a capacity for self-knowledge and realization of new experience appeared;

- attitude changed toward itself and to the surrounding world;

- possibility independently to work out the problems appeared, doing a choice, making decision and bearing the responsibility for it;

- understanding of problem became better, itself and surrounding;

- changing of the emotional state (discharging of emotional tension, research of feelings, acceptance some from them etc.) happened;

- adaptation happened to the situation that it is impossible to change is a search and study of alternatives;

- a confidence appeared in relation to the prospects of child, own life and family overall.

In order to maintain these positive changes, we created a joint information field, which

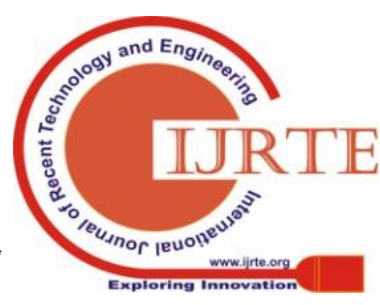


makes full communication between parents of children with psychophysical deviations in development and gives them the opportunity not only to find like-minded people, but also to understand their rights and opportunities, to take responsibility for the fate of the child and to realize their own role in the processes of life of their child.

\section{DISCUSSION}

Applying the synergistic approach to understanding the psycho-emotional states of the parents of children with disorders of psychophysical development and gaining their ability to master these conditions, we formulate it as a psychological synergy - a new direction of psychological assistance that takes into account the synergetic principles and laws regarding the person, its psycho-emotional states, the immediate environment and life . According to the synergetic approach, the family is a complex, contradictory, dynamic system that is in a state of imbalance and obeys the laws of nonlinear character. It is precisely this instability that determines the possibility of transition to a qualitatively new state with a higher level of organization and productivity, and the loss of functional unproductive sustainability triggers the mechanism of self-organization and the formation of new effective structures based on the acquired innovative potential.

This transition is due to a synergistic approach established by the psychotherapeutic alliance between a specialist (a team of specialists) and parents, which makes possible: the formulation by the parents of personal goal-setting and the definition of ways, indicators of achievement of the desired result and areas of responsibility of all participants in this process. The implemented psychological and synergistic technology of assistance to families of children with psychophysical deviations promotes the formation of the ability of parents to self-organization and self-development, carried out by the internal (improving the communication process, relationships and coherence in the family, the psychological atmosphere that promotes the development of the child) and external dimensions (formation, preserving and expanding the system of interpersonal contacts, improving their quality, regularly assessing important for the full functioning of the family of contacts and information fields, introduction into the vital activities of successive significant social events). Acquiring parents of children with psychophysical deviations of such innovative potential enables a new stage of their self-realization, which makes their family an "open system" capable of revealing, multiplying and productive use of internal and external resources, preventing the devastating influence of potentially possible risks, and realizing how from the process of self-organization and self-development depends on the success of the functioning of their child and the whole family. A new direction of psychological help - psychological synergetics, which takes into account synergetic principles and laws concerning the personality of parents of children with psychophysical deviations, their psychoemotional states, immediate environment and livelihoods, has been started. The synergetic angle translates the research of the parents of such children (and families as a whole) into the field of studying dynamic changes and allows to reveal the mechanisms of formation of personal and microsocial entities in situations of uncertainty and crisis.
The system of psychoemotional states of parents of children with psychophysical deviations of development is determined, its structural components, their hierarchy and interconnection are revealed, individual-psychological peculiarities of emotional states of parents are revealed: personal and situational anxiety, affectivity (increased emotional excitability), depression, autism, internal discomfort (emotional tension). Using the synergistic approach, the model of the process of self-organization of families with children with psychophysical deviations, which implies acquisition of the properties of an open system that can effectively use internal and external resources and fully interact with the environment, is substantiated [20].

\section{CONCLUSIONS}

The synergetic approach, which was applied to the study of the psycho-emotional states of parents of children with psychophysical deviations, deepens the scientific understanding of the personality, its crisis conditions and ways of helping it; Allows to determine the context of the functioning of parents in the family and society, both microand in macrosocial systems, and also to uncover mechanisms for effective impact on the unique structure of each family, taking into account its internal nature. It gives to the scientists and practices corresponding measuring, does integral perception of personality and society, opening of cross-coupling and achievement of the concerted joint vital functions.

We argued that the crisis of the parents, the lack of balance (on the synergistic thesaurus) launches the mechanism of self-organization and the formation of new effective structures, and this, respectively, occurs when the psychotherapeutic alliance with a specialist is established and the collegial development of the psychological support to the family strategy, and the responsibility of the parents themselves.

It is certain that exactly in the crises state (in the point of bifurcation) parents are most sensible to influence from outside and motivated to the changes. It is proved that the mechanism of self-organization and the formation of new effective structures, based on the innovative potential (ability to self-improvement, self-recovery and self-development), is launched through the establishment of trust and consistent contact with a specialist, as a condition for collegial development of an environmentally appropriate (congruent, authentic) the personality of parents and the family as a whole, the ways of development, the acquisition by them of the ability to use internal (personal) and external (micro- and macro-social) resources. The psycho-synergetic technology of helping parents of children with psychophysical deviations, whose main goal is the formation of the parents 'ability to organize themselves, provides for the parents' ability to plan the activities of the child and the family, to succeed in the situation with the child, to acquire optimal self-fulfillment in the microsocial (family) and in the macrosocial (society).

Based on the results of testing the technology of re-conducting the psycho-diagnostic examination (after the introduction of the psycho-synergistic technology of helping parents of children with psychophysical deviations), it is determined that on all previously obtained data (depression level, personal 
anxiety, child acceptance, belief in its development, ability to regulate emotional stress and awareness of their own experience, etc.) there are significant positive changes. These changes promoted and (delayed testing, after 3 months) continue to contribute to the harmonization of the psycho-emotional states of the parents, thereby improving the internal family situation in general, as well as the social adaptation of children with special needs, and the ability to self-realization of their parents.

\section{REFERENCES}

1. Baer, R.A. (2003). Mindfulness training as a clinical intervention: A conceptual and empirical review. Clinical Psychology-Science and Practice, 10:125-143. doi: 10.1093/clips'/bpg015.

2. Benn, R., Akiva T., Arel, S., Rouser, R.W. (2012). Mindfulness training effects for parents and educators of children with special needs. Developmental Psychology, 48: 1476-1487. doi: 10.1037/aw027537.

3. Benson, P.R. (2006). The impact of child symptom severity of depressed mood among parents of children with ASD: The mediating role of stress proliferation. Journal of Autism and Developmental Disorders, 36:685-695. doi: 10.1007/s10803-006-0112-3.

4. Bluth, K., Roberson, Patricia, N. E., Billen, Rhett, M., Sam,s Juli, M (2013). A Stress Model for Couples Parenting Children with Autism Spectrum Disorders and the Introduction of a Mindfulness Intervention. Journal of Family Theory and Review, 5(3): 194-213. doi: $10.1111 /$ jftr. 12015 .

5. Dabrowska, A., Pisula, E. (2010). Parenting stress and coping styles in mothers and fathers of pre-school children with autism and Down syndrome. Journal of Intellectual Disability Research. 2010; 54:266-280. doi: 10.1111/j.1365-2788.2010.01258. x.

6. Dushka, A.L. (2014). Psychological assistance to children with disorders of the emotional-volitional sphere: family-centered approach /A. Dushka// Fundamental and applied researches in practice of leading scientific schools, 6, 30-39.

7. Dushka, A. (2016). Methodology of family-oriented psychological assistance to children with emotional-volitional disorders. American Journal of Fundamental, Applied and Experimental Research, 2, 46-51.

8. Harland, K. (2002). A will of his own: Reflections on parenting a child with autism. Bethesda, MD: Woodbine House.

9. Lavin, J.L. (2001). Special kids need special parents: A resource for parents of children with special needs. New York: Berkley Books.

10. Naseef, R.A. (1997). Special children, challenged parents: The struggles and rewards of raising a child with a disability. Seacaucus, NJ: Birch Lane Press.

11. Finston, P. (1990). Parenting plus: Raising children with special health needs. New York: Dutton

12. Featherstone, H. (1980). A difference in the family: Life with a disabled child (p. 78). New York: Basic.

13. Arnold, V. I. (1981) Theory of catastrophes. - Moscow: Science, 1981.

14. Arshinov, V. I. (1999). Synergetic as a phenomenon of post-non-classical science. Moscow.

15. Vasilkova, V. V. (1999). An order and chaos are in development of frames of society. St-Petersburg.

16. Knyazeva, E. N., Kurdyumov, S. P. (1994). Laws of evolution and self-organization of the difficult systems. Moscow: Science.

17. Nikolaeva, E. M. (2005). Socialization of personality: synergetic discourse (experience of social and philosophical research). Kazan: publishing house of Kazan University.

18. Skrypnyk, T. V. (2010). Phenomenology of autism. Moscow: Publishing house "Phoenix".

19. Skrypnyk, T. (2018) Place and role of social-psychological resources in the education of children with special educational needs. PSYCHOLOGICAL JOURNAL, 15(5), pp. 142-156. doi: 10.31108/1.2018.5.15.10.

20. Dushka, A. L. (2016). Psycho-emotional state of parents of children with mental and physical disabilities: conceptualization, diagnosis, correction. Kyiv. The Institute of Special Education of the National Academy of Educational Sciences of Ukraine.

21. Tsekhmister, Ya. (2015). Ordered Structures and Self-Organization in Open Systems. Philosophy of Science eJournal, Vol 8, Issue 44, November 11, 2015. Retrieved from:

Published By:

https://hq.ssrn.com/Journals/IssueProof.cfm?abstractid=2679591\&jo $\underline{\text { urnalid }}=950426 \&$ issue number $=44 \&$ volume $=8 \&$ journal type $=C M$ BO\&function $=$ showissue

22. Tsekhmister, Ya. (1993). Flctuations Models of Self-Organizationn Ucrainian-French Symposium "Condensed Metter: Soience and Indastry" Lviv.

23. Tsekhmister, Ya. (1992). The Hopf-bifurcation in the fluctuation models of self-organization processes. Ukrainskii Fizicheskii Zhurnal, 1, 134-143.

24. Yankova, Z. (2018). Development of Special Educational Needs Support for Children and Students with Special Educational Needs. Strategies for Policy in Science \& Education / Strategii Na Obrazovatelnata i Nauchnata Politika, 26(5), 548-554.

25. López Quincha, M., Pinos Morales, G. J., Calderón Mena, X. I., Gavilánes, A. E. F., Ayala Gavilánes, D. C., \& Arellano Espinoza, F. J. (2018). La educación para la salud de niños con necesidades especiales. (Spanish). Dilemas Contemporáneos: Educación, Política y Valores, 6(1), 1-18

26. Bakkaloğlu, H., \& Sucuoğlu, B. (2018). Okul Öncesi Sınıflardaki Özel Gereksinimli Olan ve Olmayan Çocukların Okula Uyumları. (Turkish). Ilkogretim Online, 17(2), 580-595 https://doi.org/10.17051/ilkonline.2018.418906

27. Cordeiro, A., Davis, R. K., Kim, J., Berhane, Z., Turchi, R., Antonelli, R., \& Rosenberg, H. (2018). Care Coordination for Children and Youth With Special Health Care Needs: National Survey Results. Clinical Pediatrics, 57(12), 1398-1408. https://doi.org/10.1177/0009922818783501

28. Demirok, M., Akçamete, G., \& Öyken, S. (2018). Determining the requirements of families of children with special needs. Quality \& Quantity, 52(2) https://doi.org/10.1007/s11135-017-0555-y

29. Lavan, A., Reiter, S., \& Heiman, T. (2018). Educational involvement of parents of mainstreamed special needs children. Contemporary School Psychology. https://doi.org/10.1007/s40688-018-0202-1

30. Lin, C.-W., Romley, J. A., \& Carlin, C. (2018). The relationship between the patient-centered medical homes, healthcare expenditures, and quality of care among children with special health care needs. Maternal and Child Health Journal https://doi.org/10.1007/s10995-018-2572-4

31. Siddiqua, A., \& Janus, M. (2017). Experiences of parents of children with special needs at school entry: a mixed method approach. Child: Care, Health \& Development, 43(4), 566-576. https://doi.org/10.1111/cch.12443

32. Lu, M.-T. P., Ward, H. C., Overton, T., \& Shin, Y. (2014). The synergetic approach to effective teachers' research education: An innovative initiative for building educational research capacity in a Hispanic-Serving Institution. Journal of Hispanic Higher Education, 13(4), 269-284. https://doi.org/10.1177/1538192714536188 